\title{
Kidney Cancer pT3c TNM Finding v7
}

National Cancer Institute

\section{Source}

National Cancer Institute. Kidney Cancer pT3c TNM Finding v7. NCI Thesaurus. Code C89290.

Kidney cancer with tumor grossly extending into the vena cava above the diaphragm, or invading the wall of the vena cava. (from AJCC 7th Ed.) 